\title{
PENGEMBANGAN KONTEN E-LEARNING SIMULASI DIGITAL BERBASIS PROYEK UNTUK SISWA KELAS $X$ DI SMK NEGERI 1 KUBUTAMBAHAN
}

\author{
Isyarotullatifah ${ }^{1}$, I Wayan Santyasa ${ }^{2}$, Ketut Agustini ${ }^{3}$ \\ 1,2,3 Program Studi Teknologi Pembelajaran, Program Pasca Sarjana \\ Universitas Pendidikan Ganesha \\ Singaraja, Indonesia
}

e-mail: isyarotullatifah@pasca.undiksha.ac.id¹, santyasa@yahoo.com², ketutagustini@undiksha.ac.id ${ }^{3}$

\begin{abstract}
Abstrak
Penelitian ini bertujuan untuk menghasilkan produk pembelajaran berupa e-learning berbasis proyek yang valid, praktis, dan efektif bagi siswa kelas $\mathrm{X}$ semester ganjil mata pelajaran simulasi digital. Penelitian pengembangan ini didasari karena belum tersedianya bahan ajar inovatif yang sesuai dengan tuntutan Kurikulum 2013 pada mata pelajaran simulasi digital di SMK Negeri 1 Kubutambahan. Prosedur pengembangan menggunakan model AM3PU3 yang terdiri dari sepuluh tahap yaitu: (1) melakukan analisis kebutuhan, (2) melakukan kajian pustaka, (3) memilih dan menetapkan desain pengembangan, (4) melakukan tahapan pengembangan, (5) melakukan tahapan validasi, (6) menganalisis dan revisi setiap tahapan validasi, (7) menetapkan produk untuk pengujian lapangan, (8) melakukan pengujian lapangan, (9) melakukan analisis, revisi akhir, dan finalisasi produk, (10) melakukan desiminasi pada jangkauan populasi yang lebih luas.

Hasil penelitian menunjukkan bahan ajar yang dikembangkan telah memenuhi aspek validitas, kepraktisan, dan efektivitas. Hasil uji validitas menunjukkan bahwa e-learning berbasis proyek berada pada kategori sangat baik berdasarkan uji coba para ahli. Elearning juga telah memenuhi aspek kepraktisan dilihat dari respon siswa terkait kemudahan penggunaan dan kemenarikan antarmuka. Hasil uji-t menunjukkan, terdapat perbedaan yang signifikan antara nilai rata-rata hasil belajar siswa sebelum dan setelah menggunakan e-learning, di mana nilai rata-rata posttest lebih lebih besar dari nilai rata-rata pretest dan telah mencapai kriteria keberhasilan. Berdasarkan hal tersebut, e-learning berbasis proyek dinilai efektif dalam meningkatkan hasil belajar.
\end{abstract}

Kata-kata kunci: pengembangan, e-learning, simulasi digital, pembelajaran berbasis proyek

\begin{abstract}
This study aims to produce learning products in the form of a project-based e-learning that is valid, practical, and effective for students in the class $X$ semester odd digital simulation subjects. This development research is based on the unavailability of innovative teaching materials in accordance with the demands of Curriculum 2013 on digital simulation subjects in SMK Negeri 1 Kubutambahan. The development procedure uses the AM3PU3 model consisting of ten stages: (1) conducting needs analysis, (2) conducting literature review, (3) selecting and defining development design, (4) undertaking development stages, (5) performing validation stages, 6) analyzing and revising each validation stage, (7) establishing the product for field testing, (8) conducting field testing, (9) undertaking analysis, final revision, and
\end{abstract}


finalizing the product; (10) dissemination on a wider population range especially for multiyears research or long term research).

The results showed that the teaching materials developed have met the aspects of validity, practicality, and effectiveness. The results of the validity test indicate that project-based e-learning is in very good category based on expert trials. E-learning also has fulfilled the practical aspect seen from the student's response related to ease of use and interface attractiveness. The t-test results show that there is a significant difference between the mean score of student learning outcomes before and after using project-based learning. Where the posttest average value is greater than the average value of pretest and has met the minimum predefined criteria that have been set. Based on this, project-based e-learning is considered effective in improving learning outcomes.

Keywords: development, e-learning, digital simulation, project-based learning

\section{PENDAHULUAN}

Abad-21 dipahami sebagai era global yang ditandai dengan perkembangan ilmu pengetahuan dan teknologi. Era perkembangan ilmu pengetahuan dan teknologi sebenarnya menjadi momentum untuk semakin meningkatkan kualitas sumber daya manusia (SDM), termasuk SDM Indonesia. Upaya peningkatan kualitas sumber daya manusia ini, perlu didukung oleh berbagai aspek kehidupan, salah satunya pendidikan. Secara esensi, pendidikan memang merupakan aspek yang paling potensial dalam peningkatan kualitas SDM Indonesia, karena dalam praktiknya, pendidikan berkaitan dengan penyampaian ilmu pengetahuan serta nilainilai. Melalui hal tersebut, pendidikan dipahami sebagai garda terdepan dalam upaya peningkatan kualitas SDM Indonesia berbasiskan ilmu pengetahuan dan teknologi.

Simulasi digital merupakan salah mata pelajaran baru semua kompetensi keahlian pada kurikulum 2013, termasuk dalam Kompetensi Keahlian Keperawatan dan Farmasi. Simulasi digital merupakan bagian dari kelompok mata pelajaran produktif yang termasuk pada dasar program keahlian (C2) di Kurikulum 2013 yang diwajibkan pada semua program keahlian kelas $X$ Sekolah Menengah Kejuruan (SMK). Mata pelajaran ini, membekali siswa keterampilan dalam memanfaatkan teknologi informasi dan komunikasi yang pada saat ini sangat dibutuhkan dalam dunia kerja. Keterampilan yang dimaksud seperti pengelolaan informasi digital melalui perangkat lunak pengolah informasi (pengolah kata, angka, dan presentasi), dan komunikasi dalam jaringan (online). Selain itu, mata pelajaran ini bertujuan untuk membekali siswa agar dapat mengkomunikasikan gagasan atau konsep yang ditemukannya sendiri atau memodifikasi gagasan atau konsep yang sudah ada melalui media digital.

Proses pembelajaran yang selama ini dilakukan pada mata pelajaran simulasi digital sejak di terapkan kurikulum 2013 belum bisa dilakukan secara maksimal. Kondisi saat ini dalam kegiatan pembelajaran menunjukkan bahwa: a) pembelajaran masih bersifat konvensional dan teacher oriented; b) penggunaan sumber-sumber belajar belum difungsikan secara optimal; dan c) kurangnya waktu yang tersedia. Siswa belajar bersumber hanya pada guru. Sedangkan mata pelajaran Simulasi Digital ini dibutuhkan metode dan sumber belajar lain yang bisa mendukung proses pembelajaran. Pemberian pengalaman langsung, kontekstual dan berpusat kepada siswa akan memberikan dampak yang baik terhadap pengalaman belajar siswa. Dalam pengelolaan pembelajaran di sekolah, guru haruslah dapat memberikan pengetahuan peserta didik mengenai konsep yang terkandung dalam materi. Proses pembelajaran dilaksanakan dengan caracara yang lebih menyenangkan dan menarik perhatian sehingga peserta didik dapat berpartisipasi secara aktif dalam belajar. Pembelajaran yang berlangsung 
Jurnal Teknologi Pembelajaran Indonesia

ISSN: 2615-2797(Print) | ISSN: 2614-2015 (Online)

Volume 9 Nomor 1 Tahun 2019

seyogyanya menciptakan motivasi dan

lingkungan belajar yang mendukung tercapainya kompetensi dasar yang telah ditetapkan dengan menerapkan strategi pembelajaran yang sesuai.

Berdasarkan teori Van Dallen, dalam Sugiyarto (2014) hasil belajar dipengaruhi 6 faktor, yaitu: guru, kurikulum, siswa, media pembelajaran, lingkungan dan metode pembelajaran. Liliek Setiono (2009) mengatakan bahwa pemakaian media pembelajaran dalam proses pembelajaran dapat membangkitkan minat dan keinginan yang baru, membangkitkan motivasi dan rangsangan kegiatan belajar, bahkan membawa pengaruh-pengaruh psikologis terhadap peserta didik. Dalam hal ini, salah satu media pembelajaran yang dapat digunakan untuk mengoptimalkan pembelajaran Simulasi Digital adalah dengan memanfaatkan $e$ learning.

E-learning sendiri merupakan sebuah inovasi dalam pembelajaran yang memungkinkan proses pembelajaran berlangsung dengan lebih fleksibel karena tidak harus selalu terpaku di dalam kelas. Clark Aldrich (2010) menekankan definisi e-learning pada kerangka berpikir penggunaan jaringan komputer. la menyatakan bahwa e-learning merupakan sebuah kombinasi antara proses, materi dan infrastruktur dalam penggunaan komputer dan jaringannya dalam rangka meningkatkan kualitas pada satu atau lebih bagian signifikan dari aspek-aspek rangkaian kegiatan pembelajaran, termasuk di antaranya adalah aspek manajemen dan aspek pendistribusian materi pelajaran.

Dengan kemajuan teknologi diharapkan guru dapat mengembangkan pembelajaran dengan memanfaatkan teknologi informasi dan komunikasi sehingga pembelajaran menjadi lebih bermakna untuk siswa baik itu pembelajaran di sekolah maupun di luar sekolah secara mandiri. Melalui pengembangan sistem pembelajaran berupa e-learning ini diharapkan dapat mewakili peranan guru sehingga siswa dapat belajar dan memperoleh informasi serta dapat berkomunikasi secara langsung maupun tidak langsung mengenai materi yang sedang dipelajarinya. Hal ini secara tidak langsung dapat meningkatkan hasil belajar siswa. Senada dengan penelitian yang dilakukan oleh Abdelrahim (2015), mengatakan bahwa dengan penggunaan e-learning diyakini memberikan pengaruh yang baik terhadap motivasi dan hasil belajar siswa. Disisi lain ditemukan bahwa melalui $e$ learning dapat memotivasi belajar siswa dan sekaligus meningkatkan pemahaman siswa terkait materi yang dipelajarkan (Istambul, 2016). E-learning dikatakan sebagai suatu sistem yang menarik untuk digunakan dalam proses pembelajaran.

Dengan e-learning diharapkan dapat membantu siswa dalam proses belajarnya, sehingga siswa dapat berkomunikasi secara langsung maupun tidak langsung, baik itu dalam pembelajaran di kelas maupun di luar kelas. Selain itu, peserta didik dapat menggunakan waktu belajarnya dengan lebih leluasa dan memiliki kesempatan lebih besar untuk meningkatkan hasil belajarnya tanpa harus mengenyampingkan kegiatan pembelajaran yang sebenarnya di sekolah. Oleh karena itu, dalam penelitian ini dicoba dilakukan suatu pengembangan konten $e$ learning Simulasi Digital berbasis proyek untuk siswa kelas $X$ di SMK Negeri 1 Kubutambahan sebagai salah satu cara memecahkan masalah pembelajaran. Mengingat selama ini proses pembelajaran simulasi digital di kelas $X$ SMKN 1 Kubutambahan masih berpusat pada guru dan masih menggunakan metode ceramah sebagai metode utama dalam mentransfer pengetahuan, yang mana hal ini berdampak pada rendahnya pemahaman siswa terhadap materi pelajaran simulasi digital.

Berdasarkan latar belakang yang telah dipaparkan, maka permasalahan yang dijadikan dasar pada penelitian pengembangan ini sebagai berikut. 1) Bagaimanakah rancang bangun pengembangan e-learning Simulasi Digital berbasis proyek untuk siswa kelas $\mathrm{X}$ di SMK Negeri 1 Kubutambahan?; 2) 
Bagaimanakah tanggapan ahli isi, ahli media, dan ahli desain pembelajaran terhadap e-learning Simulasi Digital berbasis proyek untuk siswa kelas $X$ di SMK Negeri 1 Kubutambahan?; 3) Bagaimanakah tanggapan siswa dalam uji coba perorangan terhadap e-learning Simulasi Digital berbasis proyek untuk siswa kelas $X$ di SMK Negeri 1 Kubutambahan?; 4) Bagaimanakah tanggapan siswa dalam uji coba kelompok kecil terhadap e-learning Simulasi Digital berbasis proyek untuk siswa kelas $\mathrm{X}$ di SMK Negeri 1 Kubutambahan?; 5) Bagaimanakah tanggapan siswa dalam uji coba lapangan terhadap e-learning Simulasi Digital berbasis proyek untuk siswa kelas $X$ di SMK Negeri 1 Kubutambahan?; 6) Bagaimanakah tanggapan guru mata pelajaran terhadap $e$ learning Simulasi Digital berbasis proyek untuk siswa kelas $\mathrm{X}$ di SMK Negeri 1 Kubutambahan?; 7) Bagaimanakah efektivitas e-learning Simulasi Digital berbasis proyek yang dikembangkan terhadap hasil belajar siswa kelas X di SMK Negeri 1 Kubutambahan?

Adapun tujuan dari penelitian pengembangan ini adalah sebagai berikut. 1) Untuk mendeskripsikan rancang bangun pengembangan e-learning Simulasi Digital berbasis proyek untuk siswa kelas $\mathrm{X}$ di SMK Negeri 1 Kubutambahan; 2) Untuk mendeskripsikan tanggapan ahli isi, ahli media, dan ahli desain pembelajaran terhadap e-learning Simulasi Digital berbasis proyek untuk siswa kelas $\mathrm{X}$ di SMK Negeri 1 Kubutambahan; 3) Untuk mendeskripsikan tanggapan siswa dalam uji coba perorangan terhadap e-learning Simulasi Digital berbasis proyek untuk siswa kelas $X$ di SMK Negeri 1 Kubutambahan; 4) Untuk mendeskripsikan tanggapan siswa dalam uji coba kelompok kecil terhadap e-learning Simulasi Digital berbasis proyek untuk siswa kelas $X$ di SMK Negeri 1 Kubutambahan; 5) Untuk mendeskripsikan tanggapan siswa dalam uji coba lapangan terhadap e-learning Simulasi Digital berbasis proyek untuk siswa kelas $X$ di SMK Negeri 1 Kubutambahan; 6) Untuk mendeskripsikan tanggapan guru mata pelajaran terhadap $e$ learning Simulasi Digital berbasis proyek untuk siswa kelas $\mathrm{X}$ di SMK Negeri 1 Kubutambahan; 7) Untuk mendeskripsikan efektivitas e-learning Simulasi Digital berbasis proyek yang dikembangkan terhadap hasil belajar siswa kelas X di SMK Negeri 1 Kubutambahan.

\section{METODE}

Dalam penelitian ini peneliti menggunakan model pengembangan Santyasa (AM3PU3). Model ini terdiri atas sepuluh tahapan, yaitu: (1) melakukan analisis kebutuhan, (2) melakukan kajian pustaka, (3) memilih dan menetapkan desain pengembangan, (4) melakukan tahapan pengembangan, (5) melakukan tahapan validasi, (6) menganalisis dan revisi setiap tahapan validasi, (7) menetapkan produk untuk pengujian lapangan, (8) melakukan pengujian lapangan, (9) melakukan analisis, revisi akhir, dan finalisasi produk, (10) melakukan desiminasi pada jangkauan populasi yang lebih luas (khusus bagi multiyears research atau long term research). Setiap tahapan model ini harus dilalui secara berurutan, di mana setiap tahap pada model ini memiliki fungsi dan peranan masing-masing yang sangat mendukung keberhasilan penggunaan model. Penelitian pengembangan ini menggunakan dua metode dalam pengumpulan data yaitu kuesioner dan tes tertulis. Metode kuesioner/angket merupakan cara memperoleh atau mengumpulkan data dengan mengirimkan suatu daftar pertanyaan/pernyataan-pernyataan

kepada subjek penelitian. Metode tes tertulis merupakan cara untuk mengetahui pengetahuan, keterampilan, intelegensi atau kemampuan yang dimiliki oleh siswa dengan menggunakan serentetan pertanyaan yang berupa tes objektif. Tujuan menggunakan metode ini untuk mengetahui tingkat efektivitas penggunaan e-learning terhadap hasil belajar Simulasi Digital pada siswa kelas X SMK Negeri 1 Kubutambahan.

Instrumen yang digunakan untuk mengumpulkan data dalam penelitian 
Jurnal Teknologi Pembelajaran Indonesia

ISSN: 2615-2797(Print) | ISSN: 2614-2015 (Online)

Volume 9 Nomor 1 Tahun 2019

pengembangan ini adalah kuesioner dan

tes. Kuesioner digunakan untuk mengumpulkan data hasil review dari ahli isi bidang studi atau mata pelajaran, ahli media dan ahli desain pembelajaran, siswa saat uji coba perorangan, kelompok kecil dan lapangan. Instrumen tes objektif digunakan pada pengumpulan data uji efektivitas hasil belajar siswa untuk mendapatkan skor hasil belajar pada kegiatan pretest dan posttest baik pembelajaran sebelum menggunakan e-learning maupun pembelajaran setelah menggunakan e-learning.

Dalam penelitian pengembangan ini digunakan tiga teknik analisis data, yaitu teknik analisis deskriptif kualitatif, teknik analisis deskriptif kuantitatif, dan teknik analisis statistik inferensial (uji-t). Teknik analisis deskriptif kualitatif digunakan untuk mengolah data hasil review ahli isi bidang studi atau mata pelajaran, ahli media, ahli desain pembelajaran dan siswa. Teknik analisis deskriptif kuantitatif digunakan untuk mengolah data yang diperoleh melalui angket dalam bentuk deskriptif persentase. Rumus yang digunakan untuk menghitung persentase dari masingmasing subyek adalah sebagai berikut.

Persentase $=\frac{\sum(\text { Jawaban } \times \text { bobot tiap pilihan })}{\mathrm{n} \times \text { bobot tertinggi }} \times 100 \%$

Selanjutnya, untuk menghitung persentase keseluruhan subyek digunakan rumus sebagai berikut.

Persentase $=\mathrm{F}: \mathrm{N}$

Teknik analisis yang digunakan untuk pengujian hipotesis adalah teknik analisis uji-t. Dasar penggunaan teknik uji-t ini adalah menggunakan dua perlakuan yang berbeda terhadap satu sampel. Data dihitung dengan menggunakan SPSS.

Hasil uji coba dibandingkan $t_{\text {tabel }}$ dengan taraf signifikan 0,05 (5\%) untuk mengetahui apakah ada perbedaan yang signifikan dalam penerapan pembelajaran dengan menggunakan e-learning berbasis proyek terhadap hasil belajar Simulasi Digital pada siswa kelas $\mathrm{X}$ tahun pelajaran
$2017 / 2018$ di SMK Negeri 1

Kubutambahan.

\section{HASIL DAN PEMBAHASAN}

Dalam penelitian ini, dipaparkan tiga hasil penelitian yaitu: 1) rancang bangun pengembangan produk, 2) hasil validasi produk menurut review ahli dan uji coba produk, dan 3) efektivitas produk elearning.

Rancang bangun E-Learning. Tahap pertama dalam pengembangan konten $e$ learning Simulasi Digital berbasis proyek ini adalah menentukan mata pelajaran yang menjadi objek pengembangan. Mata pelajaran yang dipilih dalam penelitian pengembangan ini adalah mata pelajaran Simulasi Digital untuk siswa SMK. Pemilihan mata pelajaran ini didasari karena masih kurangnya sumber belajar yang digunakan serta belum adanya media pembelajaran yang bersifat inovatif pada mata pelajaran ini.

Tahap kedua adalah menganalisis kebutuhan. Pada tahap kedua dalam pengembangan konten e-learning Simulasi Digital berbasis proyek ini adalah melakukan analisis kebutuhan. Berdasarkan hasil wawancara lisan dengan guru pengajar mata pelajaran Simulasi Digital di SMK N 1 Kubutambahan dan siswa yang telah mempelajari mata pelajaran Simulasi Digital di kelas X, kondisi dalam kegiatan pembelajaran masih bersifat konvensional dan teacher oriented. Siswa tidak memiliki panduan belajar baik berupa modul cetak, lembar kerja siswa, maupun media ajar lain seperti media pembelajaran mandiri yang dapat membantu siswa dalam proses pembelajaran. Penguasaan materi simulasi digital memerlukan waktu yang tidak sedikit, hal ini disebabkan karena beragamnya materi-materi pokok yang harus dipelajari antara lain: 1) pengelolaan data digital memanfaatkan perangkat lunak pengolah data (pengolah kata, angka, presentasi, mesin pelacak, dan teknik presentasi), 2) komunikasi dalam jaringan (asinkron dan sinkron), 3) pemanfaatan kelas maya (edmodo), dan 4) perancangan visualisasi konsep. Keterbatasan waktu 
yang tersedia di sekolah dirasa tidak cukup untuk menyampaikan materi pembelajaran yang sedemikian banyak. Siswa cenderung belajar bersumber hanya pada guru. Sedangkan mata pelajaran Simulasi Digital ini dibutuhkan metode dan sumber belajar lain yang bisa mendukung proses pembelajaran.

Tahap ketiga, setelah melakukan analisis kebutuhan dilanjutkan dengan proses pengembangan draft konten $e$ learning berbasis proyek. Pada proses pengembangan draft ini dibagi menjadi dua bagian utama yaitu analisis kondisi pembelajaran dan langkah pengembangan. Analisis kondisi pembelajaran terdiri dari hal-hal sebagai berikut. 1) Analisis tujuan dan karakteristik isi bidang studi, dilakukan untuk mengetahui sasaran pembelajaran seperti apa yang hendak dicapai. 2) Analisis Sumber Belajar, dimaksudkan untuk mengetahui sumber-sumber belajar apa yang telah tersedia dan dapat digunakan untuk menyampaikan isi pembelajaran. 3) Analisis Karakteristik Pebelajar, dilakukan untuk mengetahui kualitas perseorangan yang dapat dijadikan petunjuk dalam mempreskripsikan strategi pengelolaan pembelajaran, yang hasilnya berupa daftar pengelompokan karakteristik peserta didik menjadi sasaran pembelajaran. 4) Menetapkan Indikator dan Isi Pembelajaran, langkah ini sebenarnya sudah bisa dilakukan segera setelah melakukan analisis tujuan dan karakteristik isi bidang studi, yang hasilnya berupa daftar yang memuat rumusan kompetensi dasar dan indikator pembelajaran yang akan dipelajari.

Tahapan langkah pengembangan draft draft konten e-learning berbasis proyek yakni sebagai berikut. 1) Menetapkan strategi pengorganisasian isi pembelajaran dilakukan setelah analisis dan penetapan tipe serta karakteristik materi pembelajaran. Pemilihan strategi pengorganisasian pembelajaran sangat dipengaruhi oleh tipe isi bidang studi yang dipelajari dan bagaimana struktur isi bidang studi tersebut. Strategi pengorganisasian isi pembelajaran mengacu pada pemilihan isi dan penataan isi pembelajaran. Pemilihan isi pembelajaran disesuaikan dengan tujuan pembelajaran yang harus dicapai. 2) Menetapkan Strategi Penyampaian Isi Pembelajaran, Strategi penyampaian isi pembelajaran adalah dengan menggunakan model pembelajaran project-based learning dengan langkah-langkah yaitu: 1) menetapkan tema proyek. Tema proyek hendaknya memenuhi indikator-indikator (a) memuat gagasan umum dan orisinil, (b) penting dan menarik, (c) mendeskripsikan masalah kompleks, (d) mencerminkan hubungan berbagai gagasan, (e) mengutamakan pemecahan masalah ill defined. 2) Menetapkan konteks belajar. Konteks belajar hendaknya memenuhi indikator-indikator (a) pertanyaanpertanyaan proyek mempersoalkan masalah dunia nyata, (b) mengutamakan otonomi pebelajar, (c) melakukan inquiri dalam konteks masyarakat, (d) pebelajar mampu mengelola waktu secara efektif dan efisien, (e) pebelajar belajar penuh dengan kontrol diri, (f) mensimulasikan kerja secara profesional; 3) Merencanakan aktivitasaktivitas. Pengalaman belajar terkait dengan merencanakan proyek adalah (a) membaca, (b) meneliti, (c) observasi, (d) interview, (e) merekam, (f) mengunjungi obyek yang berkaitan dengan proyek, (g) akses internet; 4) Memproses aktivitasaktivitas. Indikator-indikator memproses aktivitas adalah (a) membuat sketsa, (b) melukiskan analisa, (c) menghitung, (d) meng-generate, (e) mengembangkan prototipe; 5) Penerapan aktivitas-aktivitas untuk menyelesaikan proyek. Langkahlangkah yang dilakukan adalah (a) mencoba mengerjakan proyek berdasarkan sketsa, (b) menguji langkahlangkah yang telah dikerjakan dan hasil yang diperoleh, (c) mengevaluasi hasil yang telah diperoleh, (d) merevisi hasil yang telah diperoleh, (e) melakukan daur ulang proyek lain, (f) mengklasifikasi hasil terbaik. 3) Menetapkan Strategi Pengelolaan Pembelajaran, dilakukan mencakup penjadwalan penggunaan komponen strategi pengorganisasian dan penyampaian isi pembelajaran, dengan 
membagi alokasi waktu yang disediakan. 4) Pengukuran Hasil Pembelajaran, yang mencakup tingkat keefektifan, efisiensi, dan daya tarik pembelajaran. Kegiatan ini dilakukan dengan mengadakan pengamatan proses pembelajaran dan tes hasil belajar.

Tahap keempat, menyusun draft pengembangan. Komponen-komponen draft e-learning berbasis proyek mencakup: 1) bagian pendahuluan, 2) bagian kegiatan belajar, dan 3) bagian evaluasi.

Tahap kelima, setelah penyusunan draft pengembangan dilakukan, dilanjutkan dengan tinjauan ahli dan uji coba.

Tahap pengujian ahli terdiri dari: (1) uji ahli isi, (2) uji ahli desain pembelajaran, dan (3) uji ahli media. Hasil review pengembangan berupa e-learning oleh seorang ahli isi yang berkompeten terhadap konten khususnya pada mata pelajaran simulasi digital. Ahli isi mengkaji perihal sesuai atau tidaknya sajian materi (isi) bahan ajar dengan kompetensi yang dituntut kurikulum dan silabus. Selain itu, ahli isi juga memberikan masukan terhadap struktur penulisan dan gaya bahasa. Hal ini dimaksudkan untuk menghindari penyajian materi yang salah dan diharapkan sajian materi mudah dipahami siswa. Hasil review ahli isi menunjukan tingkat persentase pencapaian kualitas bahan ajar dari aspek isi adalah 92\%. Jika dikonversikan, maka tingkat validitas dan ketepatan aspek isi bahan ajar adalah sangat baik. Hasil ini artinya isi bahan ajar mengandung fakta, konsep, prinsip dan prosedur yang sesuai dan semuanya layak dibelajarkan kepada siswa.

Uji ahli selanjutnya adalah uji ahli desain pembelajaran. Hasil review uji ahli desain diperoleh tingkat persentase pencapaian validitas bahan aja dari aspek desain pembelajaran adalah 93\%. Jika persentase tersebut dikonversi, maka tingkat validitas bahan ajar adalah sangat baik. Ini berarti bahan ajar sudah memenuhi kelayakan aspek: 1) desain pembelajaran seperti kesesuai rumusan tujuan pembelajaran, cakupan materi, evaluasi, petunjuk belajar, dan rangkuman; 2) strategi penyampaian pesan; 3) desain antarmuka; dan 4) keotentikan tugas-tugas proyek.

Uji ahli media mengkaji kelayakan maupun kesesuaian objek-objek media yang akan digunakan dalam bahan ajar. Hal tersebut meliputi kesesuaian gambar, animasi maupun video dalam menjelaskan uraian materi, cara penyajian isi dengan media, objek yang ditampilkan dan kecocokan jenis objek multimedia dengan tujuan pembelajaran. Ahli media juga mengkaji mengenai masalah teknis dan desain fisik bahan ajar, seperti: kemudahan penggunaan, dan kemasan akhir bahan ajar. Hasil review ahli media terhadap $e$ learning berbasis proyek diperoleh tingkat persentase pencapaian validitas bahan ajar pada asepk media adalah 93,33\%. Jika dikonversikan, tingkat validitas aspek media bahan ajar adalah sangat baik. Hasil ini mengandung makna bahwa pengaturan navigasi, tampilan teks, gambar, audio, video dan animasi, kemudahan penggunaan, dan pengemasan bahan ajar sudah memenuhi standar dan layak digunakan dalam pembelajaran.

Selanjutnya dilakukan tahap uji coba perorangan yang melibatkan 3 (tiga) orang siswa kelas $X$ kompetensi keahlian Keperawatan SMK Negeri 1 Kubutambahan. Uji perorangan dilakukan setelah bahan ajar direview oleh ahli isi, ahli desain pembelajaran, ahli media, dan guru mata pelajaran. Jumlah siswa saat uji perorangan adalah tiga orang siswa yang memiliki prestasi belajar yang berbeda. Satu orang memiliki prestasi belajar yang tinggi, satu orang siswa memiliki prestasi belajar sedang dan satu orang siswa lagi memiliki prestasi belajar yang rendah, sehingga dapat dipandang sebagai sampel yang representatif. Hasil review uji coba perorangan menunjukkan persentase tingkat pencapaian $90,22 \%$ berada pada predikat sangat baik.

Uji Coba Kelompok Kecil. Tahapan ini dilakukan dengan responden sejumlah 12 orang. Pengambilan sampel dilakukan secara acak. Hasil dari uji coba kelompok kecil menunjukkan persentase tingkat pencapaian $90,11 \%$ berada pada predikat sangat baik. 
Jurnal Teknologi Pembelajaran Indonesia

ISSN: 2615-2797(Print) | ISSN: 2614-2015 (Online)

Volume 9 Nomor 1 Tahun 2019

Kemudian dilakukan uji coba lapangan. Uji coba lapangan dilakukan di kelas X Keperawatan SMK Negeri 1 Kubutambahan. Alasan pemilihan kelas ini berdasarkan pertimbangan: (1) jumlah siswa cukup banyak dibandingkan kelas lainnya (sebanyak 24 siswa), dan (2) kelas telah menggunakan Kurikulum 2013. Tujuan dilakukannya uji coba lapangan adalah untuk mengetahui respon siswa terhadap produk pengembangan yaitu $e$ learning berbasis proyek. Respon siswa dikumpulkan dengan menggunakan angket respon siswa.

Berdasarkan penilaian dari uji coba lapangan maka persentase tingkat pencapaian e-learning yang dikembangkan persentase tingkat pencapaian 91,62\% berada pada predikat sangat baik. Secara umum, e-learning yang dikembangkan mendapat tanggapan yang positif dari siswa. Siswa secara umum merasakan manfaat dari e-learning yang dikembangkan. E-learning ini juga dianggap mudah digunakan dan membantu siswa untuk mempelajari materi yang diberikan.

Hipotesis diuji dengan menggunakan uji-t (paired sample $t$-test) untuk mengetahui perbedaan skor rata-rata antara skor pretest dan posttest. Berdasarkan hasil uji-t dua sampel berpasangan (paired samples test) menunjukkan bahwa nilai $\mathrm{t}=-17,892$ dengan angka signifikansi 0.001 (yang berarti < 0.05), sehingga $\mathrm{H}_{0}$ ditolak dan $\mathrm{H}_{1}$ diterima. Hal ini berarti bahwa nilai rata-rata hasil belajar siswa antara sebelum dan sesudah menggunakan e-learning berbasis proyek tidak sama (berbeda). Kesimpulan yang dapat diambil dari hasil uji-t tersebut adalah terdapat perbedaan yang signifikan antara rata-rata nilai hasil belajar siswa sebelum menggunakan e-learning berbasis proyek dan setelah menggunakan $e$ learning berbasis proyek. Berdasarkan hasil nilai rata-rata posttest (sebesar 82.65 ) yang lebih besar dari nilai rata-rata pretest (sebesar 43.40), dapat diketahui bahwa proses pembelajaran simulasi digital dengan menggunakan e-learning berbasis proyek dapat meningkatkan hasil belajar siswa kelas $X$ SMK Negeri 1 Kubutambahan. Nilai rata-rata hasil belajar siswa pada mata pelajaran simulasi digital di kelas $X$ adalah sebesar 82.65. Nilai tersebut berada di atas nilai kriteria ketuntasan minimum (KKM) mata pelajaran simulasi yang telah ditetapkan sebesar 75 .

\section{PENUTUP \\ Simpulan}

Tahap pengembangan bahan ajar elearning menggunakan model Santyasa (AM3PU3) yang terdiri atas beberapa tahap, yaitu: 1) melakukan analisis kebutuhan; 2) melakukan kajian pustaka; 3) memilih dan menetapkan desain pengembangan; 4) melakukan tahapan pengembangan; 5) melakukan tahapan validasi; 6) menganalisis dan revisi setiap tahapan validasi; 7) menetapkan produk untuk pengujian lapangan; 8) melakukan pengujian lapangan; 9) melakukan analisis, revisi akhir, dan finalisasi produk; dan 10) melakukan desiminasi pada jangkauan populasi yang lebih luas (khusus bagi multiyears research atau long term research). Bahan ajar memiliki unsur inovatif berupa pemberian proyek-proyek. Agar mempermudah pemahaman dalam mempelajari isi, bahan ajar juga dilengkapi dengan fitur-fitur multimedia. Fitur-fitur ini membantu siswa dalam mengkontruksi konsep abstrak dan prosedur yang rumit.

Ahli isi menyatakan bahwa bahan ajar sangat baik dengan tingkat persentase sebesar 93\%. Ahli desain pembelajaran menyatakan bahwa bahan ajar sangat baik dengan peroleh persentase sebesar 93\%. Ahli media menyatakan bahwa bahan ajar sangat baik dengan peroleh persentase sebesar 93,33\%. Tanggapan uji perorangan, kelompok kecil dan lapangan menyatakan bahwa bahan ajar sangat baik dengan perolehan persentase masingmasing adalah $90,22 \%, 90,11 \%$, dan $91,62 \%$.

Berdasarkan hasil uji-t diketahui bahwa nilai rata-rata hasil belajar siswa antara sebelum dan sesudah menggunakan e-learning berbasis proyek tidak sama (berbeda). Terdapat perbedaan yang signifikan antara rata-rata nilai hasil 
belajar siswa sebelum menggunakan $e$ learning berbasis proyek dan setelah menggunakan e-learning berbasis proyek. Berdasarkan hasil nilai rata-rata posttest (sebesar 82.65) yang lebih besar dari nilai rata-rata pretest (sebesar 43.40), dapat diketahui bahwa proses pembelajaran simulasi digital dengan menggunakan $e$ learning berbasis proyek dapat meningkatkan hasil belajar siswa kelas $X$ SMK Negeri 1 Kubutambahan. Nilai ratarata hasil belajar siswa pada mata pelajaran simulasi digital di kelas $X$ adalah sebesar 82.65 dan berada di atas nilai kriteria ketuntasan minimum (KKM) mata pelajaran Simulasi Digital yang telah ditetapkan.

\section{Saran}

Berdasarkan hasil penelitian dan pembahasan terhadap media yang dikembangkan berupa e-learning berbasis proyek, dapat diajukan beberapa saran sebagai berikut.

1. E-learning berbasis proyek dikembangkan berdasarkan hasil studi pendahuluan terhadap siswa di SMK Negeri 1 Kubutambahan. Apabila ingin diterapkan di sekolah lain dengan karakteristik siswa dan lingkungan belajar yang berbeda, maka disarankan untuk melakukan perubahan seperlunya sesuai dengan kebutuhan.

2. Produk yang dihasilkan dalam pengembangan ini adalah e-learning berbasis proyek yang proses pembuatannya menggunakan software Mozilla Firefox dengan terkoneksi internet. Dalam pengembangan produk pembelajaran selanjutnya, disarankan mengembangkan jenis media inovatif lainnya seperti video pembelajaran, $e$ book, atau bentuk media lainnya.

3. Penelitian pengembangan ini dilakukan hanya terbatas pada uji efektivitas (uji-t). Oleh karena itu perlu dilakukan penelitian lebih lanjut mengenai kelayakan media sampai dengan hasil belajar yang dicapai siswa melalui penelitian eksperimen dengan menggunakan kelas pembanding.

\section{DAFTAR PUSTAKA}

Abdelrahim, M., Al-Zabadi, \& Alshura, M. S. 2015. The implementation of elearning in higher education in Saudi Arabia: U.B.T.-a case study. International Journal of Instructional Technology and Distance Learning. 12(10). 47-62. Tersedia pada http://itdl.org. Diakses 30 September 2016.

Ajai, J. T., Benjamin, I. I., \& Emmanuel, I. O. 2013. Comparison of the learning effectiveness of problem-based learning (PBL) and conventional method of teaching algebra. Journal of Education and Practice. 4(1). 131-135. Tersedia pada http://www.iiste.org. Diakses tanggal 22 September 2016.

Alammary, A., Judi, S., \& Angela, C. 2014. Blended learning in higher education: Three different design approaches. Australasian Journal of Educational Technology. 30(4). 440-454. Tersedia pada http://ajet.org.au. Diakses 30 September 2016.

Al-Tabany, T. I. B. 2014. Mendesain Model Pembelajaran Inovatif, Progresif, dan Kontekstual-Konsep, Landasan, dan Implementasinya pada Kurikulum 2013 (Kurikulum Tematik Integratif/ $K T I)$. Jakarta: Kencana.

Agung, A. A. G. 2013. Evaluasi pendidikan. Singaraja: Undiksha.

Agung, A. A. G. 2014. Metodologi penelitian pendidikan. Malang: Aditya Media Publising.

Chiang, C. L. \& Lee H. 2016. The effect of project-based learning on learning motivation and problem-solving ability of vocational high school students. International Journal of Information and Education Technology. 6(9). 709712. Tersedia pada http://www.ijiet. org. Diakses 7 Januari 2017. 
Duniawan, I G. 2014. Integrasi TIK, elearning solusi alternatif dalam kegiatan pembelajaran. Makalah. Disajikan dalam seminar problematika teknologi pendidikan jurusan teknologi pendidikan, 22 Desember 2014 di Singaraja.

Guan, C., Ding, D., \& Kong, W. H. 2015. Elearning in higher education for adult learners in Singapore. International Journal of Information and Education Technology. 5(5). 348-355. Tersedia pada http://ijiet.org. Diakses 22 September 2016.

Hiranrat, W., Narumol, R., \& Sumalee, C. 2016. Design of the contents of an elearning for teaching m.5 english language using ADDIE model. International Journal of Information and Education Technology. 6(12). 127131. Tersedia pada http://ijiet.org. Diakses 22 September 2016.

Istambul, M. R. 2016. E-learning design activity to improve student's knowledge and skills: A case study of database design courses. International Journal of Information and Education Technology. 6(6). 432-429. Tersedia pada http://ijiet.org. Diakses 22 September 2016.

Laila, Q. N. 2015. Pemikiran pendidikan moral Albert Bandura. Ejournal Kopertais IV. 3(1). 21-36. Terdapat pada http://ejournal.kopertais4.or.id. Diakses 1 Januari 2017.

Lestari, A. S. 2016. Analysis of the implementation of e-learning in STAIN Sultan Qaimuddin Kendari Southeast Sulawesi. International Journal of Informa-tion and Education Technology. 6(6). 453-456. Tersedia pada http://ijiet.org. Diakses 22 September 2016.

Mento, P. 2014. Investigate the effect of problem based learning with cooperative learning on performance. Indian
Research Journal. 1(3). Tersedia pada http://www.indianresearchjournal.com. Diakses 22 September 2016.

Nakamura, A. 2016. Self-adaptive elearning website for mathematics. Interna-tional Journal of Information and Education Technology. 6(12). 961965. Tersedia pada http://ijiet.org. Diakses 22 September 2016.

Pani, A. K., Srimannarayana, M., \& Premarajan, R. K. 2015. E-learning: Challenges and solutions - a case study. International Journal of Learning, Teaching and Educational Research. 13(4). 33-40. Tersedia pada http://ijlter.org. Diakses 2 Oktober 2016.

Raturi, S. \& Akanisi, K. 2015. Impact of elearning on primary school children and teachers: A study of the one laptop per child pilot project in Fiji. International Journal of Instructional Technology and Distance Learning. 12(8). 3-23. Tersedia pada: http://www.itdl.org/. Diakses 30 Januari 2016.

Santyasa, I W. 2009. Metode penelitian pengembangan dan teori pengembangan modul. Makalah. Disajikan dalam pelatihan bagi guru TK, SD, SMP, SMA, dan SMK tanggal 12-14 Januari 2009, di Kecamatan Nusa Penida Kabupaten Klungkung.

Santyasa, I W. 2014. Asesmen dan evaluasi pembelajaran fisika. Yogyakarta: Graha IImu.

Santyasa, I W. 2017. Pembelajaran inovatif. Singaraja: Undiksha.

Santyasa, I W. 2018. Metodologi Penelitian Pendidikan. Singaraja: Undiksha Press.

Sarfo, F. K. \& Issifu, Y. 2016. University lecturers experience in the design 
and using moodle and blended learning environments. The Online Journal of New Horizons in Education. 6(2). 143-154. Tersedia pada www.tojned.net. Diakses 22 September 2016.

Seels, B. B. \& Rita, C. R. 1994. Teknologi pembelajaran: Definisi dan kawasannya. Terjemahan oleh: Dewi, S. P., Raphael, R., \& Yusufhadi, M. Jakarta: Unit Percetakan Universitas Negeri Jakarta.

Smaldino, S. E., Lowther, D. L., \& Russel, J. D. (2008). Instructional Technology \& Media for Learning. Edisi ke 9. Diterjemahkan oleh: Arif Rahman. Jakarta: Kencana.

Soenarto. 2005. Metodologi penelitian pengembangan untuk peningkatan kualitas pembelajaran. Makalah. Disajikan pada pelatihan nasional penelitian peningkatan kualitas pembelajaran dan penelitian tindakan kelas (PPKP dan PTK) bagi dosen LPTK, 8-11 Agustus 2005 di Batam.

Sudjana, N. 2009. Penilaian hasil proses belajar mengajar. Bandung: PT Remaja Rosdakarya.

Sugiyono. 2012. Metode penelitian kuantitatif kualitatif dan $R \& D$. Bandung: Alfabeta.

Tegeh, I M. \& Kirna, I M. 2010. Metode penelitian pengembangan pendidikan. Buku Ajar (tidak diterbitkan). Singaraja: Undiksha.

Tena, R., Almenara, C. J., \& Osuna, B. J. 2016. E-Learning of Andalusian University's Lecturers. The Turkish Online Journal of Educational Technology. 12(2). 25-37. Tersedia pada: http://www.tojet.net/articles. Diakses 12 Maret 2018.

Tran, V. D. 2013. Theoretical perspectives underlying the application of cooperative learning in classrooms. International Journal of Higher Education, 2(4), 101-115. Terdapat pada http://files.eric.ed.gov/fulltext/ EJ1067527.pdf. Diakses 28 Januari 2016

Trianto. 2011. Pengantar penelitian pendidikan bagi pengembangan profesi pendidikan tenaga kependidikan. Jakarta: Kencana.

Turino, Yuliman, P., \& Arief, S. 2009. ELearning Bahasa Inggris Berbasis Web. Jurnal Teknologi Informasi. 5(2). 738-739. Tersedia pada http://jurnal.umk.ac.id. Diakses 11 Oktober 2016.

Wang, B. T., Teng, C. W., \& Lin, Y. H. 2015. Let's go traveling: Project based learning in Taiwanese classroom. International Journal of Information and Education Technology, 5(2), 8488. Terdapat pada http://www.ijiet.org/papers/481S00008.pdf. Diakses 9 Februari 2018.

Yee, R. C. S. 2015. Perceptions of online learning in an Australian University: Malaysian students' perspective support for learning. International Journal of Information and Education Technology. 5(8). 587-592. Tersedia pada http://ijiet.org. Diakses 22 September 2016.

Yudel, A. S. 2006. E-learning approach in teaching training. Turkish Online Journal of Distance EducationTOJDE. 7(4). 123-131. Tersedia pada http:// tojde.anadolu.edu.tr. Diakses 1 Oktober 2016.

Yulaelawati, E. 2004. Kurikulum dan pembelajaran filosofi teori dan aplikasi. Jakarta: Pakar Raya. 